\title{
Dark metabolism and carbonñnitrogen uncoupling in the toxic dinoflagellate Alexandrium catenella (Dinophyceae)
}

\author{
Cécile Jauzein ${ }^{a, b}$, Yves Collos ${ }^{b, ~}{ }^{*}$, Mohamed Laabir ${ }^{b}$, André Vaquer $^{b}$
}

\author{
a Ifremer, Laboratoire LER-LR, BP 171, 34203 Sète Cedex, France \\ b Université Montpellier 2 ï CNRS ï IRD (UMR 5119), Laboratoire Ecologie des Systèmes Marins Côtiers, \\ CC 093, 34095 Montpellier Cedex 5, France
}

\author{
*: Corresponding author : Yves Collos, Tel.: 33-4-6714-4744 ; Fax: 33-4-6714-3719 ; \\ email address : collos@univ-montp2.fr ; yves.collos@univ-montp2.fr
}

\begin{abstract}
:
Uptake rates of three potential $\mathrm{N}$-sources (ammonium, nitrate and $\mathrm{N}$-urea) and two potential $\mathrm{C}$ sources $\left(\mathrm{HCO}_{3}{ }^{i}\right.$ and $\mathrm{C}$-urea) were estimated during growth of Alexandrium catenella in both light and dark phases. According to the variations observed in ${ }^{13} \mathrm{C}$-isotopic ratio, $A$. catenella cells were not able to use C-urea. Furthermore, decreases in ${ }^{13} \mathrm{C}$ cell content during darkness revealed a probably high involvement of $\mathrm{C}$ recently fixed in dark respiration. Dark $\mathrm{N}$-uptake capacities of $A$. catenella were characterized by dark/light uptake ratio of $27 \%, 43 \%$ and $65 \%$ for $\mathrm{NO}_{3}{ }^{\mathrm{i}}, \mathrm{NH}_{4}{ }^{+}$and $\mathrm{N}$-urea, respectively. An accumulation of $\mathrm{C}$-rich compounds during the light period was highlighted through strong diel variations in $\mathrm{C}: \mathrm{N}$ ratio and would provide $\mathrm{C}$ and energy for these dark uptake processes indicating an uncoupling between $\mathrm{N}$ and $\mathrm{C}$ metabolism. Total costs in terms of $\mathrm{C}$ associated with dark $\mathrm{N}$-uptake and assimilation were estimated and revealed that the main part of those costs may be associated with maintenance metabolism in $A$. catenella cells. The relatively low C-costs of biosynthesis in darkness suggest that dark uptake and C-storage strategies correspond to a benefit in terms of competitiveness for $A$. catenella, optimized by the migrating abilities of this species.
\end{abstract}

\section{Highlights}

3 Dark nitrogen uptake and carbon storage of Alexandrium catenella are reported. 3 Strong diel variations in C:N ratio show uncoupling between $\mathrm{C}$ and $\mathrm{N}$ metabolism. 3 Dark/light uptake ratios are $27 \%, 43 \%$, and $65 \%$ for nitrate, ammonium, and urea. 3 Estimations of total C costs associated with dark $\mathrm{N}$ metabolism are $10 \mathrm{ï} 14 \mathrm{gC} \mathrm{gN}^{\mathrm{i} 1}$. 3 Dark $\mathrm{N}$ uptake represents a low additional cost in terms of C for this species.

$$
\begin{array}{ll}
\text { Abbreviations : } & \text { - D/L, dark:light } \\
& -\mathrm{PC} \text {, particulate carbon } \\
& -\mathrm{PN} \text {, particulate nitrogen }
\end{array}
$$

Keywords : Diel cycle ; Dark uptake ; Nitrogen ; Carbon ; Uncoupling ; Alexandrium catenella 


\section{Introduction}

Biological processes of phytoplankton cell metabolism may show a diel periodicity, initiated by extracellular oscillations in environmental growth conditions, internal variability associated with cell division cycle or circadian rhythms driven by a biological clock (cf. Sweeney, 1987; Edmunds, 1988). For phytoplankton cells, irradiance oscillation throughout the light:dark cycle corresponds to the most significant cyclic environmental variable: it can regulate metabolic processes through the influence of day or night length, maximum irradiance or spectral composition, which can act individually or in combination (Prézelin, 1992). This regulation may not only affect photosynthesis activity, but also metabolic processes dependent on end products of photosynthesis. For nutrition metabolism, nitrogen (N) uptake and assimilation may be linked with photosynthesis through different metabolic pathways (Turpin, 1991) as they require production of ATP, reducing power $(\mathrm{NAD}(\mathrm{P}) \mathrm{H})$ and carbon $(\mathrm{C})$ fixation. A strong coupling between $\mathrm{N}$ and $\mathrm{C}$ metabolism may lead to diel periodicity of $\mathrm{N}$ uptake and assimilation, provided that cells are in $\mathrm{N}$-sufficient conditions; N-limitation conditions may induce the storage of $\mathrm{C}$-rich compounds which facilitates dark nutrition processes and the decline of diel periodicity (Turpin, 1991).

In the previous study of Jauzein et al. (2008), diurnal patterns (i.e. during the light period) were highlighted for Alexandrium catenella cells and a short-term (6h) increase in C:N composition ratios was interpreted as a consequence of uncoupling between $\mathrm{C}$ and $\mathrm{N}$ uptake despite $\mathrm{N}$-sufficient conditions. The present work was conducted to carry out additional analyses of $\mathrm{N}$-uptake and $\mathrm{C}$-fixation by $A$. catenella cells throughout a complete light:dark cycle, in particular to test the potential for dark $\mathrm{N}$-uptake which would be sustained by $\mathrm{C}$ accumulation during the day as reflected by the diurnal increase in $\mathrm{C}: \mathrm{N}$ ratio. Three potential $\mathrm{N}$-sources that are known to yield similar growth rates for $A$. catenella (Collos et al., 2004) were tested: nitrate $\left(\mathrm{NO}_{3}{ }^{-}\right)$, ammonium $\left(\mathrm{NH}_{4}{ }^{+}\right)$and $\mathrm{N}$-urea. Some phytoplankton species are capable of utilizing urea not only as a N-source, but also as a C-source (Lomas, 2004). This study gave the opportunity to test the potential use of C-urea by $A$. catenella cells.

\section{Materials and methods}

\subsection{Culture conditions}

The $A$. catenella strain (ACT03) used in this study was isolated from the Thau lagoon in 2003. Cultures were maintained at $20^{\circ} \mathrm{C}$ on ESAW artificial seawater (Andersen et al., 2005) with nitrate $\left(\mathrm{NO}_{3}{ }^{-}\right)$as $\mathrm{N}$-source. Cells were grown on a 12:12 h light:dark cycle using a photon flux density of $100 \mu \mathrm{mol}$ photons $\mathrm{m}^{-2} \mathrm{~s}^{-1}$.

\subsection{Experimental procedures}

To investigate the diel variations of $\mathrm{N}$ and $\mathrm{C}$-uptake by $A$. catenella cells, two experiments were conducted in batch cultures, based on the same experimental design but different ranges of $\mathrm{N}$-addition: (1) in the first one, $\mathrm{N}$-additions were performed to ensure $\mathrm{N}$-sufficient conditions all along the experiment duration, (2) in the second one, lower $\mathrm{N}$-additions were made to allow a depletion of $\mathrm{N}$-sources before the end of the experiment. The last experiment was also performed to test the potential uptake of C-urea. As N-uptake and assimilation vary with the growth rate (Maguer et al., 2007), one 3 L-stock culture in exponential growth phase was used for each experiment to ensure that cells were in similar growth conditions. 
Each experiment started at the beginning of the light period with the resuspension of $A$. catenella cells in $3 \mathrm{~L}$ of ESAW medium without $\mathrm{N}$-source using an $11 \mu \mathrm{m}$ mesh size net. To avoid modifications of metabolic processes due to agitation during repeated sampling, the resuspended culture was immediately split in $40 \mathrm{ml}$-aliquots and different ${ }^{15} \mathrm{~N}$ and ${ }^{13} \mathrm{C}$ additions were performed.

In the first experiment (1) four series of samples were run for testing three different $\mathrm{N}$ sources $\left(\mathrm{NO}_{3}{ }^{-}, \mathrm{NH}_{4}{ }^{+}\right.$and urea) in $\mathrm{N}$-sufficient conditions, one series without $\mathrm{N}$-addition being used as a control. $\mathrm{N}$-sources were added as ${ }^{15} \mathrm{~N}$-labeled nutrient at an initial concentration between 66 and $140 \mu$ gat N L L ${ }^{-13} \mathrm{C}$-labeled bicarbonate $\left(\mathrm{NaH}^{13} \mathrm{CO}_{3}{ }^{-}\right)$was added simultaneously at $78 \mu \mathrm{M}-\mathrm{C}$ in each sample.

The second experiment (2) tested three $\mathrm{N}$-conditions, applying lower pulses of urea (15 $\mu$ gat $\left.\mathrm{N} \mathrm{L}^{-1}\right)$ or $\mathrm{NH}_{4}^{+}\left(15 \mu\right.$ gat $\left.\mathrm{L}^{-1}\right)$ or no $\mathrm{N}$-addition leading to $\mathrm{N}$ exhaustion over the short term. Four series of samples were performed as follow: addition of ${ }^{15} \mathrm{~N}-{ }^{13} \mathrm{C}$-urea only, addition of ${ }^{15} \mathrm{~N}-{ }^{13} \mathrm{C}$-urea and $\mathrm{NaH}^{13} \mathrm{CO}_{3}^{-}$, addition of ${ }^{15} \mathrm{NH}_{4}{ }^{+}$and $\mathrm{NaH}^{13} \mathrm{CO}_{3}^{-}$, and neither ${ }^{15} \mathrm{~N}$ nor ${ }^{13} \mathrm{C}$-addition. Pulses of $\mathrm{H}^{13} \mathrm{CO}_{3}{ }^{-}$corresponded to $78 \mu \mathrm{M}-\mathrm{C}$ additions.

Incubations started with the addition of ${ }^{15} \mathrm{~N}$ and ${ }^{13} \mathrm{C}$-sources and samples were immediately replaced in the culture chamber under initial conditions. During each experiment, at least one aliquot was used every hour during light periods and every $2 \mathrm{~h}$ (except for one missing incubation time) during dark periods for parameters measurements. Experiments (1) and (2) lasted 26 and $29 \mathrm{~h}$ to ensure a complete diel cycle.

\subsection{Chemical and biological parameters}

Each incubation was ended with sample filtration through precombusted (4h at $450{ }^{\circ} \mathrm{C}$ ) $\mathrm{A} / \mathrm{E}$ filters (Gelman Sciences, Ann Arbor, MI, USA). Measurements of nutrient concentrations were performed from the filtrate using the methods of Collos et al. (1999), Koroleff (1976) and Goeyens et al. (1998) respectively for $\mathrm{NO}_{3}{ }^{-}, \mathrm{NH}^{+}$and urea. Filters were dried at $60{ }^{\circ} \mathrm{C}$ overnight and kept at room temperature until analysis. Estimations of particulate nitrogen (PN), particulate carbon (PC) and ${ }^{15} \mathrm{~N} /{ }^{14} \mathrm{~N}$ and ${ }^{13} \mathrm{C} /{ }^{12} \mathrm{C}$ isotopic ratios were obtained from filters analysis on an Integra $\mathrm{CN}$ elemental analysis-mass spectrometry system (PDZ Europa, UK). Uptake rates were calculated from the regressions of isotopic ratios vs. time using equations in Collos (1987). Total costs in terms of carbon loss associated with $\mathrm{N}$ uptake and assimilation into $A$. catenella cells during darkness were estimated from variations in PC relatively to changes in PN (æPC / æPN) using the following equations:

$$
\begin{gathered}
\frac{\Delta \mathrm{PC}}{\Delta \mathrm{PN}}=\frac{\mathrm{a}}{\mathrm{b}} \times \mathrm{C}: \mathrm{N}_{1} \\
\text { with } \quad \mathrm{a}=\frac{\Delta \mathrm{PC}}{\mathrm{PC}_{1}}=\frac{\mathrm{C}: \mathrm{N}_{2}}{\mathrm{C}: \mathrm{N}_{1}} \times(\mathrm{b}+1)-1 \\
\text { and } \quad \mathrm{b}=\frac{\Delta \mathrm{PN}}{\mathrm{PN}_{1}}=\frac{1-{ }^{12} \mathrm{~N} \text {-atom } \%-1}{1-{ }^{15} \mathrm{~N} \text {-atom } \%-2}-1
\end{gathered}
$$

where, for each variable $\mathrm{X}$ (particulate carbon, $\mathrm{PC}$; particulate nitrogen, $\mathrm{PN}$; ratio between $\mathrm{PC}$ and $\mathrm{PN}, \mathrm{C}: \mathrm{N} ;{ }^{15} \mathrm{~N} /{ }^{14} \mathrm{~N}$ isotopic ratio, ${ }^{15} \mathrm{~N}$-atom\%), $\mathrm{X}_{1}$ and $\mathrm{X}_{2}$ represent the values obtained at the beginning and at the end of the dark period, respectively.

Those total costs estimates are based on $\mathrm{C}: \mathrm{N}$ values and ${ }^{15} \mathrm{~N} /{ }^{14} \mathrm{~N}$ isotopic ratios $\left(\mathrm{C}: \mathrm{N}_{1}, \mathrm{C}: \mathrm{N}_{2}\right.$, ${ }^{15} \mathrm{~N}$-atom\%-1, ${ }^{15} \mathrm{~N}$-atom\%-2) obtained from data regressions during the dark period. They include costs of $\mathrm{N}$ uptake and assimilation as well as all other processes taking place during 
the dark period, such as uptake of other nutrients or maintenance metabolism. The equation (3) relies on the hypothesis defining the uptake of ${ }^{14} \mathrm{~N}$ as negligible. This postulate leads to the relation æPN $=\mathrm{P}^{15} \mathrm{~N}_{2} \ddot{I} \quad \mathrm{P}^{15} \mathrm{~N}_{1}=\mathrm{PN}_{2} \times{ }^{15} \mathrm{~N}$-atom\%-2 $\mathrm{I} \quad \mathrm{PN}_{1} \times{ }^{15} \mathrm{~N}$-atom\% $\%_{-1}$ that can be easily modified to obtain equation (3).

Comparisons between groups used either ANOVAs followed by Tukey $\hat{\mathbf{S}}$ multiple comparison tests or unpaired $t$ tests depending on the number of groups compared. Statistical analyses were done with Prism software (GraphPad Software Inc.). All statistics are based upon the multiple time points collected during each light/dark phase.

\section{Results}

Considering variations of $\mathrm{NH}_{4}{ }^{+}$concentrations in the series of samples where an initial ${ }^{15} \mathrm{~N}$ urea addition was performed, no extensive $\mathrm{NH}_{4}^{+}$release, associated with the urea assimilation process, was observed during both experiments (Fig. 1). Thus, no N-losses have to be taken into account in the analysis of ${ }^{15} \mathrm{~N}$-isotopic ratios.

\subsection{Experiment in $\mathrm{N}$-replete conditions}

For the first experiment (1), a linear decrease in nutrient concentrations was observed with time for the three series of samples performed with an initial ${ }^{15} \mathrm{~N}$-addition. Despite this consumption, nutrient concentrations remained above $12 \mu$ gatN L $\mathrm{L}^{-1} \mathrm{until}$ the end of the experiment: final concentrations were 81, 69 and $12 \mu$ gat $\mathrm{N} \mathrm{L}^{-1}$ for $\mathrm{NO}_{3}{ }^{-}, \mathrm{NH}_{4}{ }^{+}$and urea respectively.

A. catenella cells were capable of using the three $\mathrm{N}$-sources, $\mathrm{NO}_{3}{ }^{-}, \mathrm{NH}_{4}{ }^{+}$and urea, during the light and the dark periods (Fig. 2). Considering data of each consecutive light/dark period, most appeared to increase linearly with time, indicating a constant uptake rate. To compare $\mathrm{N}$-uptake capacities of $A$. catenella cells under the different nutrient and light conditions, linear regressions of the ${ }^{15} \mathrm{~N}$-ratios as a function of time were computed for each light/dark period. Mean uptake rates estimated from regression slopes are presented in Table 1 with corresponding standard deviations and $\mathrm{R}^{2}$ values. For the first light period, all $\mathrm{N}$ uptake rates were different from each other $(\mathrm{p}<0.001)$, with $\mathrm{NH}_{4}{ }^{+}$uptake being the highest and $\mathrm{N}$-urea the lowest. For the dark period, $\mathrm{NH}_{4}^{+}$uptake was significantly higher than $\mathrm{NO}_{3}{ }^{-}(\mathrm{p}<0.001)$ or $\mathrm{N}$ urea $(p<0.001)$ uptake. Dark uptake rates corresponded to $27 \%, 43 \%$ and $65 \%$ of light uptake rates for $\mathrm{NO}_{3}{ }^{-}, \mathrm{NH}_{4}{ }^{+}$and $\mathrm{N}$-urea respectively.

${ }^{13} \mathrm{C}$ cell contents showed increases in the light and decreases in the dark for all series of samples (Fig. 3). The first linear rise, identified between 0 and $6 \mathrm{~h}$, allowed the definition of maximal ${ }^{13} \mathrm{C}$-uptake rates $\left(\mathrm{V}_{\text {max }-\mathrm{c}}\right)$ from regression slopes (Table 1$)$. Uptake rates obtained were very close between series $\left(0.028 \pm 0.003 \mathrm{~h}^{-1}\right)$, but the $\mathrm{V}_{\text {max-c }}$ estimated for the ${ }^{15} \mathrm{NH}_{4}{ }^{+}$ series was significantly lower than values of both ${ }^{15} \mathrm{~N}$-urea and control series $(\mathrm{p}<0.001)$. After 17:00, ${ }^{13} \mathrm{C}$-uptake rates appeared to slow down during the $3 \mathrm{~h}$ preceding the dark period (20:00). Linear decreases in ${ }^{13} \mathrm{C}$ isotopic ratios were then observed during darkness, characterized by similar negative slopes for the four series of samples with a mean of $0.0037 \pm 0.0004 \mathrm{~h}^{-1}$ (NS).

$\mathrm{C}: \mathrm{N}$ composition ratios revealed a clear diel cycle showing a general increase during the light period followed by a decrease during the dark period (Fig. 4). During the first light period, the largest increase in $\mathrm{C}: \mathrm{N}$ ratios was noted for the series without initial $\mathrm{N}$-pulse, reaching 12.1 molC molN ${ }^{-1}$. All slopes were significantly different ( $p$ ranging from $<0.001$ to $<0.05$ ) with the ranking: control $>$ urea $>\mathrm{NO}_{3}{ }^{-}>\mathrm{NH}_{4}{ }^{+}$. Data obtained between $9 \mathrm{~h}$ and $21 \mathrm{~h}$ of incubation were 
used to estimate regression slopes associated with decreases in darkness (Table 1): slope values between -0.07 and -0.20 molC molN ${ }^{-1} \mathrm{~h}^{-1}$ were obtained, with the lowest calculated for the ${ }^{15} \mathrm{~N}$-urea series (significantly lower than values estimated for the ${ }^{15} \mathrm{NH}_{4}{ }^{+}$and control series, $\mathrm{p}<0.001$ ) and the highest for the ${ }^{15} \mathrm{NH}_{4}{ }^{+}$series.

Integrating $\mathrm{C}: \mathrm{N}$ variations along the first $24 \mathrm{~h}$ (limit indicated by a dashed line on Fig. 4), C:N ratios measured at the end of the complete diel cycle $\left(\mathrm{C}: \mathrm{N}_{24 \mathrm{~h}}\right)$ were 9.0, 7.3, 9.3 and 11.1 for the ${ }^{15} \mathrm{NO}_{3}^{-},{ }^{15} \mathrm{NH}_{4}^{+},{ }^{15} \mathrm{~N}$-urea and control series respectively. For the ${ }^{15} \mathrm{NH}_{4}^{+}$series, the $\mathrm{C}: \mathrm{N}_{24 \mathrm{~h}}$ value was close to the initial value of 6.8 , indicating that the increase during the light period was entirely compensated by the decrease in darkness. Such compensation was only partial for the other series. Similar C: $\mathrm{N}_{24}$ values were obtained for the series based on ${ }^{15} \mathrm{NO}_{3}{ }^{-}$and ${ }^{15} \mathrm{~N}$-urea and corresponded to the initial ratio increased by $33 \%$ and $37 \%$ respectively. The series without $\mathrm{N}$-addition showed the greatest increase (64\%) between initial C:N and C: $\mathrm{N}_{24 h}$. $\mathrm{C}: \mathrm{N}$ values and ${ }^{15} \mathrm{~N}$ isotopic ratios were used to estimate total costs associated with $\mathrm{N}$-uptake and assimilation into $A$. catenella cells during darkness. Respective costs of 14.2, 13.7 and $10.3 \mathrm{gC} \mathrm{gN}^{-1}$ were calculated for ${ }^{15} \mathrm{NO}_{3},{ }^{-15} \mathrm{NH}_{4}{ }^{+}$and ${ }^{15} \mathrm{~N}$-urea series.

\subsection{Experiment with $\mathrm{N}$-depletion}

For the second experiment (2), an initial pulse of $15 \mu$ gat $\mathrm{L}^{-1}$ of $\mathrm{NH}_{4}^{+}$or $\mathrm{N}$-urea was performed for three of the four series of samples. Nutrient depletion occurred during the first light period $(5 \mathrm{~h} 30)$ for the ${ }^{15} \mathrm{NH}_{4}{ }^{+}$series and at the end of the dark period $(21 \mathrm{~h})$ for the ${ }^{15} \mathrm{~N}$ ${ }^{13} \mathrm{C}$-urea series (Fig. 1). This difference came from the maximal $\mathrm{N}$-uptake rate measured during the light period for the ${ }^{15} \mathrm{NH}_{4}{ }^{+}$series $\left(0.026 \pm 0.001 \mathrm{~h}^{-1}\right)$ that was found to be three times higher (significantly, $t=35.5, p<0.0001$ ) than the one measured for ${ }^{15} \mathrm{~N}-{ }^{13} \mathrm{C}$-urea series $\left(0.007 \pm 0.001 \mathrm{~h}^{-1}\right)$. These uptake rates were estimated from the linear part of the increase in cellular ${ }^{15} \mathrm{~N}$ isotopic ratio with time (Fig. 5). Variations in ${ }^{15} \mathrm{~N}$ isotopic ratio were similar for both ${ }^{15} \mathrm{~N}-{ }^{13} \mathrm{C}$-urea series, so associated results were considered as replicates and are reported on Fig. 5 as mean values. As in the first experiment in $\mathrm{N}$-replete conditions, $\mathrm{N}$ urea uptake rate was measured also during the dark period, with a ratio between dark and light uptake rates of $53 \%$. Increases observed in ${ }^{15} \mathrm{~N}$ cell contents ended with nutrient depletion and values were then globally maintained at a constant level until the end of the experiment, $15.2 \pm 0.9{ }^{15} \mathrm{~N}$-atom \% and $10.3 \pm 0.7{ }^{15} \mathrm{~N}$-atom \% for the ${ }^{15} \mathrm{NH}_{4}{ }^{+}$- and the ${ }^{15} \mathrm{~N}$ ${ }^{13} \mathrm{C}$-urea series respectively.

Assimilation of ${ }^{13} \mathrm{C}$ by $A$. catenella cells was measured only for samples where an initial addition of $\mathrm{H}^{13} \mathrm{CO}_{3}^{-}$had been performed (Fig. 6). When comparing ${ }^{13} \mathrm{C}$ isotopic ratios of the series based on ${ }^{15} \mathrm{~N}-{ }^{13} \mathrm{C}$-urea addition (without $\mathrm{H}^{13} \mathrm{CO}_{3}^{-}$) and the series without initial pulses of ${ }^{15} \mathrm{~N}$ and ${ }^{13} \mathrm{C}$, results were found equivalent, suggesting that $A$. catenella cells were not able to use urea as a C-source. Variations in ${ }^{13} \mathrm{C}$-ratios observed for the other series with $\mathrm{H}^{13} \mathrm{CO}_{3}{ }^{-}$ additions $\left({ }^{15} \mathrm{NH}_{4}^{+}+\mathrm{H}^{13} \mathrm{CO}_{3}^{-}\right.$and ${ }^{15} \mathrm{~N}-{ }^{13} \mathrm{C}$-urea $\left.+\mathrm{H}^{13} \mathrm{CO}_{3}{ }^{-}\right)$showed trends similar to those highlighted under $\mathrm{N}$-replete conditions: increases during the light periods and decreases during the dark period, however decreases appeared exponential rather than linear in this second experiment. As no ${ }^{13} \mathrm{C}$-assimilation was noted after an initial addition of ${ }^{15} \mathrm{~N}-{ }^{13} \mathrm{C}$-urea only, variations observed for the series compiling both potential ${ }^{13} \mathrm{C}$-sources, ${ }^{15} \mathrm{~N}-{ }^{13} \mathrm{C}$-urea and $\mathrm{H}^{13} \mathrm{CO}_{3}^{-}$, were representative of ${ }^{13} \mathrm{C}$ assimilation from $\mathrm{H}^{13} \mathrm{CO}_{3}^{-}$exclusively and allowed estimations of $\mathrm{H}^{13} \mathrm{CO}_{3}^{-}$uptake rates. $\mathrm{V}_{\text {max-c }}$ from $\mathrm{H}^{13} \mathrm{CO}_{3}^{-}$estimated during the first light period were $0.040 \pm 0.003 \mathrm{~h}^{-1}$ and $0.046 \pm 0.004 \mathrm{~h}^{-1}$ for the series based on ${ }^{15} \mathrm{NH}_{4}{ }^{+}$and ${ }^{15} \mathrm{~N}$ ${ }^{13} \mathrm{C}$-urea respectively (significant difference, $\mathrm{t}=3.4, \mathrm{p}=0.003$ ). 


\section{Discussion}

\subsection{Dark $\mathrm{N}$-uptake under $\mathrm{N}$-sufficient conditions}

Among the three potential $\mathrm{N}$ sources tested $\left(\mathrm{NO}_{3}{ }^{-} \mathrm{NH}_{4}{ }^{+}\right.$and $\mathrm{N}$-urea ) for $\mathrm{A}$. catenella, $\mathrm{NH}_{4}{ }^{+}$seems to be the preferred $\mathrm{N}$-source during both light and dark phases. Results from the experiment (1) allow the characterization of dark $\mathrm{N}$-uptake capacities under $\mathrm{N}$-sufficient conditions. These nutritive conditions can be justified referring to $\mathrm{N}$-uptake kinetics reported for A. catenella cells by Collos et al. (2004) and Jauzein et al. (2008) (strains ACT2000 and ACT03 respectively): $A$. catenella cells were able to sustain maximal $\mathrm{N}$-uptake rates all over the experiment (1) duration according to ranges of $\mathrm{NO}_{3}{ }^{-}, \mathrm{NH}_{4}{ }^{+}$and $\mathrm{N}$-urea concentrations observed. During the light period, the mean $\mathrm{N}$-urea uptake rate estimated in the present study under $\mathrm{N}$-sufficient conditions is low compared to the maximum uptake rate $\left(\mathrm{V}_{\max }=\right.$ $0.025 \pm 0.008 \mathrm{~h}^{-1}$ ) reported by Collos et al. (2004) for cells acclimated to urea as a N-source, however. If differences between strains in terms of $\mathrm{N}$-urea uptake capacities may explain such a discrepancy (Jauzein et al. 2008), potential interferences due to preconditioning effects cannot be rejected and may have limited $\mathrm{N}$-urea uptake capacities of $A$. catenella cells in the present study. Only relative data of uptake rates between light and dark periods are discussed below; these ratio values might be less sensitive to potential interferences due to preconditioning.

Abilities of marine microalgae to carry out uptake at night under $\mathrm{N}$-sufficient conditions are observed for various taxonomic groups, including dinoflagellates, prymnesiophytes and diatoms (Paasche et al., 1984; Clark et al., 2002; Needoba and Harrison, 2004). No global classification of phytoplankton taxonomic groups may be proposed on such a basis because reported capacities vary strongly between genera of the same class and even between species of the same genus. For dinoflagellates, a high variability inside genera can be highlighted for Prorocentrum, Heterocapsa or Alexandrium from previous studies (Table 2). Concerning $\mathrm{NO}_{3}$ and $\mathrm{NH}_{4}{ }^{+}, A$. catenella shows low capacities for $\mathrm{N}$-uptake at night, with respective dark:light $(\mathrm{D} / \mathrm{L})$ uptake ratios of $27 \%$ and $43 \%$ when reported $\mathrm{D} / \mathrm{L}$ uptake ratios for other species under $\mathrm{N}$-sufficient conditions range from $1 \%$ to $75 \%$ for $\mathrm{NO}_{3}{ }^{-}$and from $21 \%$ to $100 \%$ for $\mathrm{NH}_{4}{ }^{+}$(Clark et al., 2002;Granumet al., 2002; Needoba and Harrison, 2004; Table 2). Dark N-urea uptake capacities of phytoplankton cells in $\mathrm{N}$-sufficient conditions are much less studied than $\mathrm{NO}_{3}{ }^{-}$or $\mathrm{NH}_{4}{ }^{+}$. The estimation of $\mathrm{D} / \mathrm{L} \mathrm{N}$-urea uptake ratio for $A$. catenella $(65 \%$; present study) is in the range of values reported for the diatom Phaeodactylum tricornutum (35\%; Rees and Syrett, 1979) and the dinoflagellate Alexandrium tamarense (98

\%; Leong et al., 2010; see Table 2). According to Sinclair et al. (2009), dark uptake and assimilation abilities may also vary between strains of the same species, revealing specific adaptations to different environmental conditions. From the study of three strains of Karenia brevis isolated from different geographic regions, they obtained ranges of $\mathrm{D} / \mathrm{L}$ uptake ratios of $55 \%-136 \%$ for $\mathrm{NH}_{4}{ }^{+}$and $32 \%-89 \%$ for $\mathrm{N}$-urea, but from cultures that were $\mathrm{N}$-depleted and maintained under low light.

\subsection{Uncoupling between photosynthesis and nutrient uptake}

Dark N-uptake capacities in photosynthetic cells are dependent on particular metabolic adaptations. Nutrient uptake and assimilation in darkness require an additional expense of previously fixed $C$ to be supplied with energy (ATP), reductant $(N A D(P) H)$ and C-skeletons, creating an uncoupling between photosynthesis and nutrition processes (Cosper, 1982). Photosynthetic $\mathrm{C}$ fixed in excess during the light period may be stored into $\mathrm{C}$-rich and $\mathrm{N}$-free macromolecules, such as carbohydrates (Cuhel et al. 1984; Clark and Flynn, 2002; Granum et al. 2002) or neutral lipids (Fábregas et al. 2002) which can account for $10-50 \%$ of the dry 
weight of the cell (Geider and La Roche, 2002). Accumulation of large pools of C-rich storage compounds may modify significantly C:N and C:P ratios (Geider and La Roche, 2002).

In the present study, strong diel variations in $\mathrm{C}: \mathrm{N}$ ratio were observed for $A$. catenella cells growing on $\mathrm{NO}_{3}{ }^{-}, \mathrm{NH}_{4}{ }^{+}$and $\mathrm{N}$-urea, but also for the control series without $\mathrm{N}$-addition. $\mathrm{C}$ uptake from urea did not interfere in these trends as $A$. catenella cells were not able to use urea as a C-source (Fig. 6) under the light levels used in the present study (100 عmol photons. $\left.\mathrm{m}^{-2} \cdot \mathrm{s}^{-1}\right)$. Similar detailed patterns of $\mathrm{C}: \mathrm{N}$ diel variations were described for species maintained under $\mathrm{N}$-replete conditions, such as Skeletonema costatum (Burkhardt et al.1999b), Thalassiosira weissflogii (Clark et al. 2002) and Emiliana huxleyi (Bucciarelli et al., 2007), and N-limited conditions, as for Dunaliella tertiolecta (Sciandra et al., 1997). For dinoflagellates, the only study reporting variations of $\mathrm{C}: \mathrm{N}$ during the light:dark cycle to our knowledge is the one of Maclntyre et al. (1997) on A. tamarense. Even if samples were taken only twice daily on a 14h:10h light:dark cycle in this study, C:N oscillations were visible for $A$. tamarense cells maintained under $\mathrm{N}$-replete conditions when measurements were done around the middle of successive light and dark periods.

Under $\mathrm{N}$-sufficient conditions, an increase in $\mathrm{C}: \mathrm{N}$ during the light period suggests that photosynthetic $\mathrm{C}$ is stored in excess relatively to requirements for $\mathrm{N}$-uptake and assimilation. In darkness, a decrease results from $\mathrm{C}$ losses, through respiration and DOC excretion and $\mathrm{N}$-uptake at night. In the present study, the large C:N decrease observed for the control series (without $\mathrm{N}$-addition) suggests that $\mathrm{C}: \mathrm{N}$ variations in darkness are mainly governed by $\mathrm{C}$-losses and the main part of these losses are independent of dark N-uptake and assimilation. For $A$. catenella, storage of $\mathrm{C}$-rich compounds from photosynthesis may mostly balance the high $\mathrm{C}$-requirement for maintenance respiration in darkness.

\subsection{Variations of ${ }^{13} \mathrm{C}$-isotopic ratio during the light:dark cycle}

Analysis of ${ }^{13} \mathrm{C}$-isotopic ratios sustains the hypothesis that most of C-fluxes in $A$. catenella cells during the light:dark cycle are not dependent on dark $\mathrm{N}$-uptake and assimilation. During the light period, ${ }^{13} \mathrm{C}$-uptake rates reveal that $A$. catenella cells maintain an optimized photosynthetic activity during the main part of the light period, with a drop in C-uptake rate noted during the $3 \mathrm{~h}$ preceding the dark phase. $\mathrm{V}_{\max -\mathrm{C}}$ values obtained during the light period of the experiment (1) do not mirror the differences in terms of C-requirements associated with dark $\mathrm{N}$-uptake and assimilation: close $\mathrm{V}_{\max -\mathrm{C}}$ values were estimated from the four series of samples (growth on $\mathrm{NO}_{3}{ }^{-}, \mathrm{NH}_{4}{ }^{+}, \mathrm{N}$-urea or without $\mathrm{N}$-addition) and the lowest value is not associated with the control.

During the dark phase, similar variations in ${ }^{13} \mathrm{C}$-isotopic ratio vs. time were also observed from the different nutritive conditions of growth. These decreases in ${ }^{13} \mathrm{C}$-isotopic ratio could result either from an unbalanced loss of carbon (loss of products enriched in ${ }^{13} \mathrm{C}$ relatively to natural abundance) or from dilution of the PC labeling by uptake of unlabelled organic products. The second hypothesis was previously proposed by Collos et al. (2006) to explain a concomitant decrease in both ${ }^{13} \mathrm{C}$ - and ${ }^{15} \mathrm{~N}$-isotopic ratios of $A$. catenella cells in cultures once the extracellular concentration of inorganic nitrogen was exhausted. However, results obtained in experiment (2) (Fig. 5) did not reveal a decrease in ${ }^{15} \mathrm{~N}$ cell content after exhaustion of ${ }^{15} \mathrm{NH}_{4}{ }^{+}$(during the first light period) or ${ }^{15} \mathrm{~N}$-urea (at the end of the dark phase). Thus, if uptake of unlabelled organic compounds has occurred during experiments (1) and (2), this process would not be the only one to contribute to the decrease in ${ }^{13} \mathrm{C}$ cell contents noted during the dark phase.

Concerning the first hypothesis and according to Burkhardt et al. (1999a), an unbalanced loss of carbon may be the result of either a loss of ${ }^{13} \mathrm{C}$-enriched dissolved organic carbon from the cell, or fractionation processes associated with carboxylation/decarboxylation reactions or finally complete decarboxylation of ${ }^{13} \mathrm{C}$-rich organic compounds. The latter 
process is likely to have contributed the most to the trends observed. According to Geider and Osborne (1989), dinoflagellates may be characterized by high ratios between dark respiration and maximum net photosynthesis rates, generally higher than $25 \%$ and reaching up to $59 \%$. In the present results, ${ }^{13} \mathrm{C}$-decreases during darkness represented $12-15 \%$ of the maximal $\mathrm{C}$-uptake $\left(\mathrm{V}_{\max -\mathrm{c}}\right)$ estimated during the previous photophase. Based on the ratios of dark respiration vs.net photosynthesis proposed by Geider and Osborne (1989), a contribution of $20-60 \%$ of ${ }^{13} \mathrm{C}$ in the pool of $\mathrm{C}$ respired during the dark phase may explain slopes of ${ }^{13} \mathrm{C}$-decrease observed for $A$. catenella cells. Thus, the decrease in ${ }^{13} \mathrm{C}$ cell content in darkness may proceed from the complete decarboxylation of ${ }^{13} \mathrm{C}$-rich organic compounds synthesized during the previous photophase, reflecting a high involvement in dark respiration of $\mathrm{C}$ recently fixed. Furthermore, the similar decreases obtained for the series with and without $\mathrm{N}$-addition may suggest a high involvement of maintenance metabolism in dark respiration.

\subsection{Metabolic costs associated with dark metabolism}

If a part of the energy requirements of phototrophic cells during the light phase can be provided by photosynthesis, dark respiration corresponds to the exclusive source of ATP and reductant during darkness at the expense of $\mathrm{C}$-storage reserves (carbohydrates or neutral lipids) used as substrates (Geider and Osborne 1989). Assuming a coupling in respiratory energy conversion, dark respiration rates can be used to estimate energy requirements associated with maintenance metabolism and biosynthesis during darkness. In the present study, variations in $\mathrm{C}: \mathrm{N}$ ratio and cell content in terms of ${ }^{13} \mathrm{C}$ and ${ }^{15} \mathrm{~N}$ allow the analysis of the respective energy requirements for dark $\mathrm{N}$-uptake and assimilation compared to basal metabolism in $A$. catenella cells.

Variations observed in $\mathrm{C}: \mathrm{N}$ and ${ }^{15} \mathrm{~N}$-isotopic ratios of $A$. catenella cells during the dark phase were used to estimate total costs (combining biosynthesis and basal metabolism) in terms of $\mathrm{C}$ loss associated with dark $\mathrm{N}$-uptake and assimilation of $\mathrm{NO}_{3}{ }^{-}, \mathrm{NH}_{4}{ }^{+}$and $\mathrm{N}$-urea. These costs based on material budgets are comparable with the values reported for the diatom Thalassiosira weissflogii by Clark et al. (2002). Uptake and assimilation of $\mathrm{NO}_{3}$ and $\mathrm{N}$-urea in darkness are associated with higher energy requirement and C-reserve mobilization than $\mathrm{NH}_{4}{ }^{+}$. For $\mathrm{NO}_{3}{ }^{-}$, the additional energetic expense comes from the requirement of ATP, reductant and enzyme synthesis $\left(\mathrm{NO}_{3}{ }^{-}\right.$and $\mathrm{NO}_{2}{ }^{-}$reductases) for the reduction of $\mathrm{NO}_{3}{ }^{-}$ successively into nitrite $\left(\mathrm{NO}_{2}^{-}\right)$and $\mathrm{NH}_{4}^{+}$(Syrett,1981). This may lead to a cost of $\mathrm{N}$ assimilation into protein (derived from cell $\mathrm{C}$ budget) four times higher for $\mathrm{NO}_{3}{ }^{-}$than $\mathrm{NH}_{4}{ }^{+}$ (Syrett, 1956; Penning de Vries et al., 1974) and may explain the stronger dependence on light noted for $\mathrm{NO}_{3}{ }^{-}$uptake for several marine phytoplankton species (Clark and Flynn, 2002; Clark et al., 2002; Table 2). For $A$. catenella, the limitation of $\mathrm{NO}_{3}{ }^{-}$dark uptake by the energetic demand is confirmed from estimations of costs in terms of $\mathrm{C}$ : a similar value was obtained (around $14 \mathrm{~g} \mathrm{C} \mathrm{g} \mathrm{N}^{-1}$ ) for both $\mathrm{NO}_{3}^{-}$and $\mathrm{NH}_{4}{ }^{+}$, while dark uptake rate of $\mathrm{NO}_{3}^{-}$ represents less than half the rate of $\mathrm{NH}_{4}{ }^{+}$.

With a D/L uptake ratio of $65 \%$ associated with a total C-cost of $10 \mathrm{~g} \mathrm{C} \mathrm{g} \mathrm{N}^{-1}, \mathrm{~N}$-urea uptake appears less dependent on light than $\mathrm{NO}_{3}{ }^{-}(27 \%)$ and $\mathrm{NH}_{4}{ }^{+}(43 \%)$ even though $\mathrm{N}$-urea assimilation includes a transformation step of urea into $\mathrm{NH}_{4}{ }^{+}$involvingureaseactivity. A similar ranking of $\mathrm{D} / \mathrm{L}$ uptake ratios as a function of oxidation state $(<10 \%, 66 \%, 98 \%$ respectively for $\mathrm{NO}_{3}^{-}, \mathrm{NH}_{4}^{+}$and $\mathrm{N}$-urea) was reported by Leong et al. (2010) for $A$. tamarense cells maintained semi-continuously at $100 \mu \mathrm{M}-\mathrm{N}$. An explanation of this lowest dependence on light noted for $\mathrm{N}$-urea uptake could lie in the potential use of urea as a $\mathrm{C}$-source which would facilitate dark nutrition processes; present results show that $A$. catenella is not able to use $\mathrm{C}$ urea, however. 
The total C-costs associated with dark uptake and assimilation of $\mathrm{NO}_{3}{ }^{-}$and $\mathrm{NH}_{4}{ }^{+}$by $A$. catenella cells appear to be much higher than values $\left(<3 \mathrm{~g} \mathrm{C} \mathrm{g} \mathrm{N}^{-1}\right)$ reported for the diatom T. weissflogii in N-replete conditions (Clark et al., 2002). If higher costs can arise from inefficiency in respiratory energy conversion leading to increased C-reserve consumption, this cannot explain the discrepancy observed. According to variations in $\mathrm{C}: \mathrm{N}$ ratio and ${ }^{13} \mathrm{C}$ cell content, $A$. catenella can be characterized by high maintenance costs that contribute mainly to C-losses in darkness. Thus, differences in total C-costs noted between $A$. catenella and the diatom may rely on maintenance metabolic energy requirements more than on costs associated with dark $\mathrm{N}$-uptake and assimilation.

Geider and Osborne (1989) reported a high involvement of maintenance metabolism in dark respiration for the close species $A$. tamarense. $A$. tamarense is characterized by a high maintenance respiration rate $\left(0.30 \mathrm{~d}^{-1}\right)$ compared to other species (Ó $0.2 \mathrm{~d}^{-1}$ for 4 out of 32 cases), and in particular to $T$. weissflogii (average of $0.04 \mathrm{~d}^{-1}$ under the light:dark cycle, Table 3 in Geider and Osborne, 1989). Furthermore, even if $A$. tamarense shows a strong dependence of dark respiration on growth, its low growth rate probably limits a lot the contribution of biosynthesis in dark respiration: the maintenance respiration rate $r_{0}=0.30 \mathrm{~d}^{-}$ ${ }^{1}$ represents $55 \%$ to $70 \%$ of the total dark respiration rate $r_{d}\left(d^{-1}\right)$ when a maximum growth rate $\left(\varepsilon, d^{-1}\right)$ of $0.3 d^{-1}-0.6 d^{-1}$ (Laabir et al., 2011) is used in the linear relationship $r_{d}\left(d^{-1}\right)=r_{0}$ $\left(d^{-1}\right)+0.40 \times \varepsilon\left(d^{-1}\right)$ defined by Geider and Osborne (1989) for A. tamarense.

Difference in maintenance costs between flagellates and diatoms cannot be explained by motility as synthesis and use of flagella are likely to be of minor metabolic costs (Raven and Richardson, 1984). We suggest that a significant part of the difference observed between Alexandrium spp. and T. weissflogii may come from costs associated with protein turnover. Protein turnover is considered to be one of the most significant components of maintenance processes (Penning de Vries, 1975; Raven et al. 2000). When T. weissflogii is characterized by a protein content of $40-60 \mathrm{~g}$ prot. $\mathrm{L}^{-1}$ cell volume (Price, 2005), a two-times higher protein content (90-130 g prot. $\mathrm{L}^{-1}$ cell volume) can be estimated for $A$. tamarense from estimations of Murata et al (2006) standardized by cell volumes reported by Sullivan and Swift (2003). The higher total C-costs associated with dark uptake of $\mathrm{NO}_{3}^{-}$and $\mathrm{NH}_{4}{ }^{+}$estimated for $A$. catenella (present study) compared to T. weissflogii (Clark et al., 2002) could be due to higher maintenance respiration rate and more specifically protein turnover in dinoflagellates.

\subsection{Ecological implications}

According to Litchman et al. (2004), the impact of the dark N-uptake strategy on species competitiveness depends on the duration of the light period in the diel cycle (dependent on the day length and the mixing depth in situ) and on the energetic cost of the nutrient uptake and assimilation. For $A$. catenella, additional costs associated with dark uptake and assimilation may not reduce the competitiveness of this species as they appear to be low compared to maintenance costs. Furthermore, the higher $\mathrm{D} / \mathrm{L}$ uptake ratio obtained for $\mathrm{N}$ urea uptake of Alexandrium cells compared to $\mathrm{NH}_{4}{ }^{+}$(Leong et al. 2010; present study) suggests that costs of uptake and assimilation may not be the only metabolic parameters interfering in costs-benefits of dark uptake strategy.

For flagellate species such as $A$. catenella, benefits from dark uptake strategy are also linked with their ability to migrate actively in the water column. Migration behavior during the diel cycle allows the improvement of dark $\mathrm{N}$-uptake at night optimizing nutrient conditions, as well as $\mathrm{C}$ storage capacities during the daylight optimizing irradiance conditions. In a reverse and complementary way, accumulation of C-rich compounds over the daylight may increase the specific density of cells and favor the passive sinking to the deeper layers at night. Such a role of carbohydrates as ballast may have an ecological interest also for non-flagellate phytoplankton species, such as diatoms: intracellular accumulation of carbohydrates in 
response to nutritive stress may trigger cell sinking into deeper layers where more nutrient sufficient conditions may be encountered (Richardson and Cullen, 1995). However, this buoyancy regulation process operates over longer time scales than diel variations. Thus, even if some diatoms species show higher $\mathrm{D} / \mathrm{L}$ uptake ratios than $A$. catenella in $\mathrm{N}$-replete cultures (Clark et al., 2002; Needoba and Harrison, 2004), the potential benefits of their dark uptake strategy in situ can be higher for the latter species, in particular in water columns where nutrients distribution is not homogenous.

Flynn et al. (2002) consider that dinoflagellates may have a competitive disadvantage for dark uptake and assimilation due to their relatively $\mathrm{N}$-rich status, which may reduce $\mathrm{C}$ availability for supporting dark metabolism processes. Under $\mathrm{N}$-replete conditions, detailed diel variations of $\mathrm{C}: \mathrm{N}$ ratio do not support this hypothesis: differences between the minimum and maximum value of $\mathrm{C}: \mathrm{N}$ over the diel cycle were reported to be 1.7 and 4.7 for two diatoms (Bukhardt et al., 1999b; Clark et al. 2002), 1.0 for a prymnesiophyte (Bucciarelli et al., 2007) and 2.9 for the dinoflagellate $A$. catenella (present study). According to these values, potential $\mathrm{C}$-storage availability does not appear to be a competitive disadvantage for A. catenella.

\section{Conclusions}

Experiments performed have allowed the test of two potential nutritive strategies of $A$. catenella cells: dark $\mathrm{N}$-uptake and C-urea uptake capacities. A. catenella cells show no ability to use $\mathrm{C}$-urea, but they are characterized by dark $\mathrm{N}$-uptake capacities at the expense of previously fixed carbon with a high efficiency for the dissolved organic source N-urea. In situ, the efficiency of these dark $\mathrm{N}$-uptake and $\mathrm{C}$-storage strategies may be optimized by the ability of the cells to migrate actively. The analysis of costs in terms of C-losses associated with biosynthesis processes and basal metabolism in darkness revealed that specific C-costs of dark $\mathrm{N}$-uptake and assimilation may be negligible compared to cell maintenance in $A$. catenella. This suggests that the dark $\mathrm{N}$-uptake strategy corresponds to a benefit in terms of competitiveness for this species.

\section{Acknowledgements}

This study was financed by CNRS (Centre National de la Recherche Scientifique) and Ifremer (Institut Français de Recherche pour IExploitation de la Mer) ALTOX program. C. J. was supported by a scholarship from the Région Languedoc-Roussillon and Ifremer.

\section{References}

Andersen, R.A., Berges, J.A., Harrison, P.J., Watanabe, M.M., 2005. Recipes for freshwater and seawater media. In: Andersen, R.A. (Ed.), Algal culturing techniques. Elsevier, Amsterdam, pp. 429-538.

Bucciarelli, E., Sunda, W.G., Belviso, S., Sarthou, G.,2007. Effect of the diel cycle on production of dimethylsulfoniopropionate in batch cultures of Emilianahuxleyi.Aquat.Microb.Ecol. 48,73-81.

Burkhardt, S., Riebesell, U., Zondervan, I., 1999a. Stable carbon isotope fractionation by marine phytoplankton in response to daylength, growth rate, and $\mathrm{CO}_{2}$ availability. Mar.Ecol. Prog.Ser.184,31-41. 
Burkhardt, S., Zondervan, I., Riebesell, U., 1999b. Effect of $\mathrm{CO}_{2}$ concentration an C:N:P ratio in marine phytoplankton: A species comparison. Limnol.Oceanogr.44,683-690.

Clark, D.R., Flynn, K.J., 2002. N-assimilation in the noxious flagellate Heterosigmacarterae (Raphidophyceae): dependence on light, N-source, and physiological state. J. Phycol. 38, 503-512.

Clark, D.R., Flynn, K.J., Owens, N.J.P., 2002. The large capacity for dark nitrate-assimilation in diatoms may overcome nitrate limitation of growth. New Phytol.155, 101-108.

Collos, Y., 1987. Calculations of ${ }^{15} \mathrm{~N}$ uptake rates by phytoplankton assimilating one or several nitrogen sources. Int. J. Appl. Radiat. Isot.38, 275-282.

Collos, Y., Mornet, F., Sciandra, A., Waser, N., Larson, A., Harrison, P.J., 1999. An optical method for the rapid measurement of micromolar concentrations of nitrate in marine phytoplankton cultures.J. Appl. Phycol. 11, 179-184.

Collos, Y., Gagne, C., Laabir, M., Vaquer, A., Cecchi, P., Souchu, P., 2004. Nitrogenous nutrition of Alexandriumcatenella (Dinophyceae) in cultures and in Thau Lagoon, Southern France.J. Phycol.40, 96-103.

Collos, Y., Lespilette, M., Vaquer, A., Laabir, M., Pastoureaud, A., 2006. Uptake and accumulation of ammonium by Alexandriumcatenella during nutrient pulses. Afr. J. Mar. Sci.28, 313-318.

Cosper, E., 1982. Influence of light intensity on diel variations in rates of growth, respiration and organic release of a marine diatom: comparison of diurnally constant and fluctuating light. J. Plankton Res.4, 705-724.

Cuhel, R.L., Ortner, P.B., Lean, D.R.S., 1984.Night synthesis of protein by algae.Limnol. Oceanogr.29, 731-744.

Edmunds, L.N., 1988.Cellular and molecular bases of biological clocks.Springer-Verlag, New York.

Fábregas, J., Maseda, A., Domínguez, A., Ferreira, M., Otero, A., 2002. Changes in the cell composition of the marine microalga, Nannochloropsis gaditana, during a light:dark cycle. Biotechnol. Lett. 24, 1699-1703.

Flynn, K.J., Clark, D.R., Owens, N.J.P. 2002. Modelling suggests that optimization of dark nitrogen-assimilation need not be a critical selective feature in phytoplankton. New Phytol. 155, 109-119.

Geider, R., Osborne, B.A., 1989.Respiration and microalgal growth: a review of the quantitative relationship between dark respiration and growth. New Phytol.112, 327341.

Geider, R., La Roche, J., 2002. Redfield revisited: variability of C:N:P in marine microalgae and its biochemical basis. Eur. J. Phycol.37, 1-17.

Goeyens, L., Kindermans, N., Abu Yusuf, M., Elskens, M., 1998. A room temperature procedure for the manual determination of urea in seawater.Estuar. Coast. Shelf S.47, 415-418.

Granum, E., Kirkvold, S., Myklestad, S.M., 2002. Cellular and extracellular production of carbohydrates and amino acids by the marine diatom Skeletonemacostatum: diel variations and effects of $\mathrm{N}$ depletion. Mar. Ecol. Prog.Ser.242, 83-94.

Jauzein, C., Collos, Y., Garcés, E., Vila, M., Maso, M., 2008. Short-term temporal variability of ammonium and urea uptake by Alexandriumcatenella (Dynophyta) in cultures.J. Phycol.44, 1136-1145.

Koroleff, F., 1976.Determination of nutrients. In:Grasshoff, K. (Ed.),Methods of Seawater analysis. VerlagChemie, Weinheim, pp. 117-182.

Laabir, M., Jauzein, C., Genovesi, B., Masseret, E., Grzebyk, D., Cecchi, P., Vaquer, A., Perrin, I., Collos, Y., 2011. Importance of temperature, salinity and irradiance on the growth and cell yield of the harmful red tide dinoflagellate Alexandrium catenella colonizing Mediterranean waters. J. Plankton Res. In press (doi: 10.1093/plankt/fbr050)

Leong, S.C.Y., Maekawa, M., Taguchi, S., 2010. Carbon and nitrogen acquisition by the toxic dinoflagellateAlexandriumtamarense in response to different nitrogen sources and supply modes.Harmful Algae 9, 48-58.Litchman, E., Klausmeier, C.A., Bossard, P., 
2004.Phytoplankton nutrient competition under dynamic light regimes.Limnol. Oceanogr. 49, 1457-1462.

Lomas, M.W., 2004. Does urea-carbon contribute significantly to Aureococcusanophagefferens carbon nutrition? In:Steidinger, K.A., Landsberg, J.H., Tomas, C.R., Vargo, G.A. (Eds.), Harmful algae 2002. Florida Fish and Wildlife Conservation Commission, Florida Institute of Oceanography, and Intergovernmental Oceanographic Commission of UNESCO, 402-404.

Mac1ntyre, J.G., Cullen, J.J., Cembella, A.D. 1997. Vertical migration, nutrition and toxicity in the dinoflagellateAlexandriumtamarense. Mar. Ecol. Prog. Ser. 148, 201-216.

Maguer, J.F., LAHelguen, S., Madec, C., Labry, C., Le Corre, P., 2007. Nitrogen uptake and assimilation kinetics in Alexandriumminutum (Dynophyceae): effect of $\mathrm{N}$-limited growth rate on nitrate and ammonium interactions. J. Phycol. 43, 295-303.

Murata, A., Leong, S.C., Nagashima, Y., Taguchi, S., 2006. Nitrogen:Phosphorus supply ratio may control the protein and total toxin of dinoflagellate Alexandrium tamarense. Toxicon. 48, 683-689.

Needoba, J.A., Harrison, P.J., 2004. Influence of low light and a light:dark cycle on NO3 uptake, intracellular NO3, and nitrogen isotope fractionation by marine phytoplankton. J. Phycol.40, 505-516.

Paasche, E., Bryceson, I., Tangen, K., 1984.Interspecific variation in dark nitrogen uptake by dinoflagellates. J. Phycol.20, 394-401.

Penning de Vries, F.W.T., 1975. The cost of maintenance processes in plant cells. Annals of Botany. 39, 77i 92.

Penning de Vries, F.W.T, Brunsting, A.H.M., Van Laar, H.H., 1974. Products, requirements and efficiency of biosynthesis: a quantitative approach. J. Theoret. Biol. 45, 339-377.

Prézelin, B.B., 1992. Diel periodicity in phytoplankton productivity. Hydrobiologia. 238, 1-35.

Price, N.M., 2005. The elemental stoichiometry and composition of an iron-limited diatom. Limnol. Oceanogr., 50, 1149-1158.

Raven, J.A., Richardson, K., 1984. Dinoflagellate flagella: a costï benefit analysis. New Phytol. 98, 259ï 276.

Raven, J.A., Külber, J.E., Beardall, J., 2000. Put out the light, then put out the light. J. Mar. Biol. Assoc. U. K. 80, 1-27.

Rees, T.A.V., Syrett, P.J., 1979.The uptake of urea by the diatom, Phaeodactylum. New Phytol. 82, 169-178.

Richardson, T.L., Cullen, J.J., 1995. Changing in buoyancy and chemical composition during growth of a coastal marine diatom: ecological and biogeochemical consequences. Mar. Ecol. Prog Ser.129, 77-90.

Sciandra, A., Gostan, J., Collos, Y., Descolas-Gros, C., Leboulanger, C., Martin-Jézéquel, V., Denis, M., Lefèvre, D., Copin-Montégut, C., Avril, B., 1997. Growth-compensating phenomena in continuous cultures of Dunaliella tertiolecta limited simultaneously by light and nitrate. Limnol. Oceanogr. 42, 1325-1339.

Sinclair, G., Kamykowski, D., Glibert, P.M., 2009. Growth, uptake, and assimilation of ammonium, nitrate, and urea, by three strains of Kareniabrevis grown under low light. Harmful Algae 8, 770-780.

Sullivan, J.M., Swift, E., 2003. Effects of small-scale turbulence on net growth rate and size of ten species of marine dinoflagellates. J. Phycol. 39, 83ï 94.

Sweeney, B.M., 1987. Rhythmic phenomena in plants ( $2^{\text {nd }}$ edn). Academic Press, New York.

Syrett, P.J., 1956. The assimilation of ammonia and nitrate by nitrogen-starved cells of Chlorella vulgaris. III. Differences of metabolism dependent on the nature of the nitrogen source. Physio. Planta. 9, 28-37.

Syrett, P.J., 1981. Nitrogen metabolism of microalgae. In: Platt, T.(Ed.), Physiological bases of phytoplankton ecology. Canadian Bulletin of Fisheries and Aquatic Sciences 210, pp. 182-210.

Turpin, D.H., 1991. Effects of inorganic $\mathrm{N}$ availability on algal photosynthesis and carbon metabolism.J. Phycol.27,14-20. 
Tables

Table 1

Estimations of ${ }^{15} \mathrm{~N}$-uptake rates $\left(V_{\mathrm{N}}\right.$ in $\left.\mathrm{h}^{-1}\right),{ }^{13} \mathrm{C}$-uptake rates $\left(V_{\max -\mathrm{C}}\right.$ in $\left.\mathrm{h}^{-1}\right)$ and slopes from regressions of C: $\mathrm{N}$ ratio vs. time for $A$. catenella cells during the light and dark periods, for the four series of samples (controls without $\mathrm{N}$-addition).

\begin{tabular}{|c|c|c|c|c|c|c|}
\hline & \multicolumn{2}{|l|}{${ }^{15} \mathrm{~N}$-uptake } & \multicolumn{2}{|l|}{${ }^{13} \mathrm{C}$-uptake } & \multicolumn{2}{|c|}{$\mathrm{C}: \mathrm{N}$ composition ratio } \\
\hline & $V_{\mathrm{N}}$ & $R^{2}$ & $V_{\max -\mathrm{C}}$ & $R^{2}$ & Slope & $R^{2}$ \\
\hline \multicolumn{7}{|c|}{ First light period } \\
\hline$+{ }^{15} \mathrm{NO}_{3}^{-}$ & $0.012( \pm 0.001)$ & 0.96 & $0.028( \pm 0.003)$ & 0.94 & - & - \\
\hline$+^{15} \mathrm{NH}_{4}^{+}$ & $0.018( \pm 0.001)$ & 0.99 & $0.025( \pm 0.002)$ & 0.97 & - & - \\
\hline$+{ }^{15} \mathrm{~N}$-urea & $0.005( \pm 0.001)$ & 0.85 & $0.031( \pm 0.001)$ & 0.99 & - & - \\
\hline Control & - & - & $0.030( \pm 0.003)$ & 0.96 & - & - \\
\hline \multicolumn{7}{|l|}{ Dark period } \\
\hline$+{ }^{15} \mathrm{NO}_{3}{ }^{-}$ & $0.003( \pm 0.001)$ & 0.98 & - & - & $0.139( \pm 0.032)$ & 0.79 \\
\hline$+^{15} \mathrm{NH}_{4}{ }^{+}$ & $0.008( \pm 0.001)$ & 0.92 & - & - & $0.196( \pm 0.054)$ & 0.73 \\
\hline$+{ }^{15} \mathrm{~N}$-urea & $0.003( \pm 0.001)$ & 0.95 & - & - & $0.071( \pm 0.020)$ & 0.71 \\
\hline Control & - & - & - & - & $0.156( \pm 0.024)$ & 0.89 \\
\hline
\end{tabular}

$R^{2}$ values correspond to each data regression. ${ }^{13} \mathrm{C}$-uptake rates $\left(V_{\max -\mathrm{C}}\right)$ were estimated from the linear part of variations in ${ }^{13} \mathrm{C}$-isotopic ratio. Standard deviations in parentheses. 
Table 2

Dark/light uptake ratios (in \%) reported for dinoflagellates species from culture experiments in $\mathrm{N}$-sufficient conditions.

\begin{tabular}{llllll}
\hline \multirow{2}{*}{ Genera } & Species & \multicolumn{2}{l}{ Nutrient } & \multirow{2}{l}{ Reference } \\
\cline { 3 - 5 } & & $\mathrm{NO}_{3}{ }^{-}$ & $\mathrm{NH}_{4}{ }^{+}$ & $\mathrm{N}$-urea & \\
\hline Amphidinium & carterae & $\mathrm{NA}$ & 65 & $\mathrm{NA}$ & Paasche et al. (1984) \\
Gymnodinium & galatheanum & 12 & $\mathrm{NA}$ & $\mathrm{NA}$ & Paasche et al. (1984) \\
Gyrodinium & aureolum & 1 & 21 & $\mathrm{NA}$ & Paasche et al. (1984) \\
Scrippsiella & trochoidea & 29 & 44 & $\mathrm{NA}$ & Paasche et al. (1984) \\
Prorocentrum & micans & 15 & 36 & $\mathrm{NA}$ & Paasche et al. (1984) \\
& minimum & 60 & 86 & $\mathrm{NA}$ & Paasche et al. (1984) \\
Heterocapsa & triquetra & 75 & 108 & & Paasche et al. (1984) \\
& illdefina & $<20$ & $\mathrm{NA}$ & $\mathrm{NA}$ & Clark et al. (2002) \\
Alexandrium & catenella & 27 & 43 & 65 & Present study \\
& tamarense & $<10$ & 66 & 98 & Leong et al. (2010) \\
\hline
\end{tabular}

Among the different $\mathrm{N}$-conditions tested in the study of Leong et al. (2010), data presented here were obtained from cultures maintained semi-continuously on $100 \mu \mathrm{M}-\mathrm{NO}_{3}{ }^{-}$, under the culture mode called "continuous- $\mathrm{N}$ supply". 
Fig. 1. Variations of urea and ammonium concentrations in Alexandrium catenella cultures where an initial ${ }^{15} \mathrm{~N}$-urea addition was performed to ensure $\mathrm{N}$-replete conditions over $24 \mathrm{~h}$ (a) or short-term depletion of urea (b). Series of samples with supplementary addition of $\mathrm{H}^{13} \mathrm{CO}_{3}{ }^{-}$ are represented by black symbols (urea, black diamonds; ammonium, black triangles) and series without by white symbols (urea, white circles; ammonium, white squares).

a)

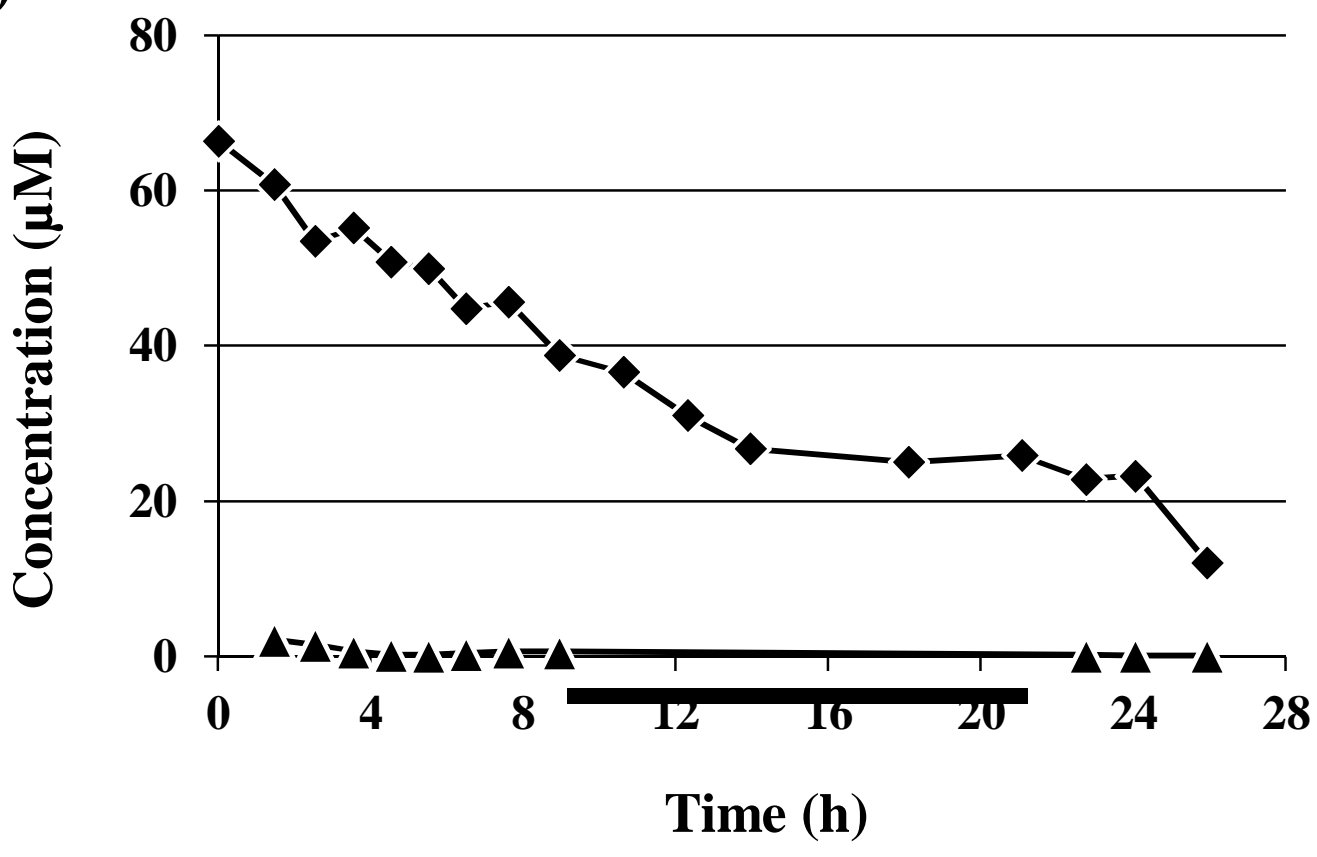

b)

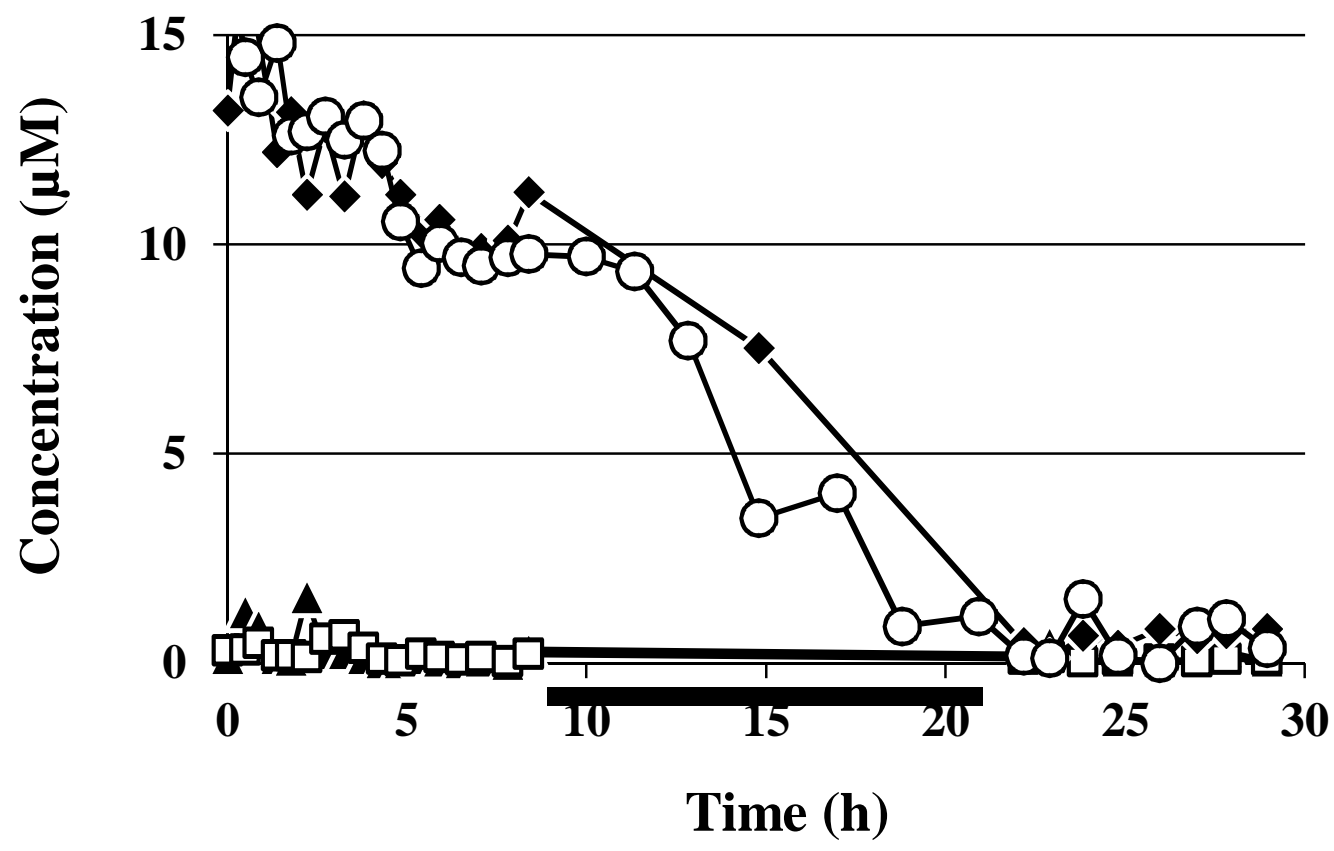


Fig. 2. Variations in ${ }^{15} \mathrm{~N}$ isotopic ratios of Alexandrium catenella cells in $\mathrm{N}$-sufficient conditions, with ${ }^{15} \mathrm{NH}_{4}{ }^{+},{ }^{15} \mathrm{NO}_{3}$ or ${ }^{15} \mathrm{~N}$-urea additions, and without $\mathrm{N}$-addition. The dark period is indicated by the horizontal solid line and the end of the complete light:dark cycle $(24 \mathrm{~h})$ by the vertical dotted line.

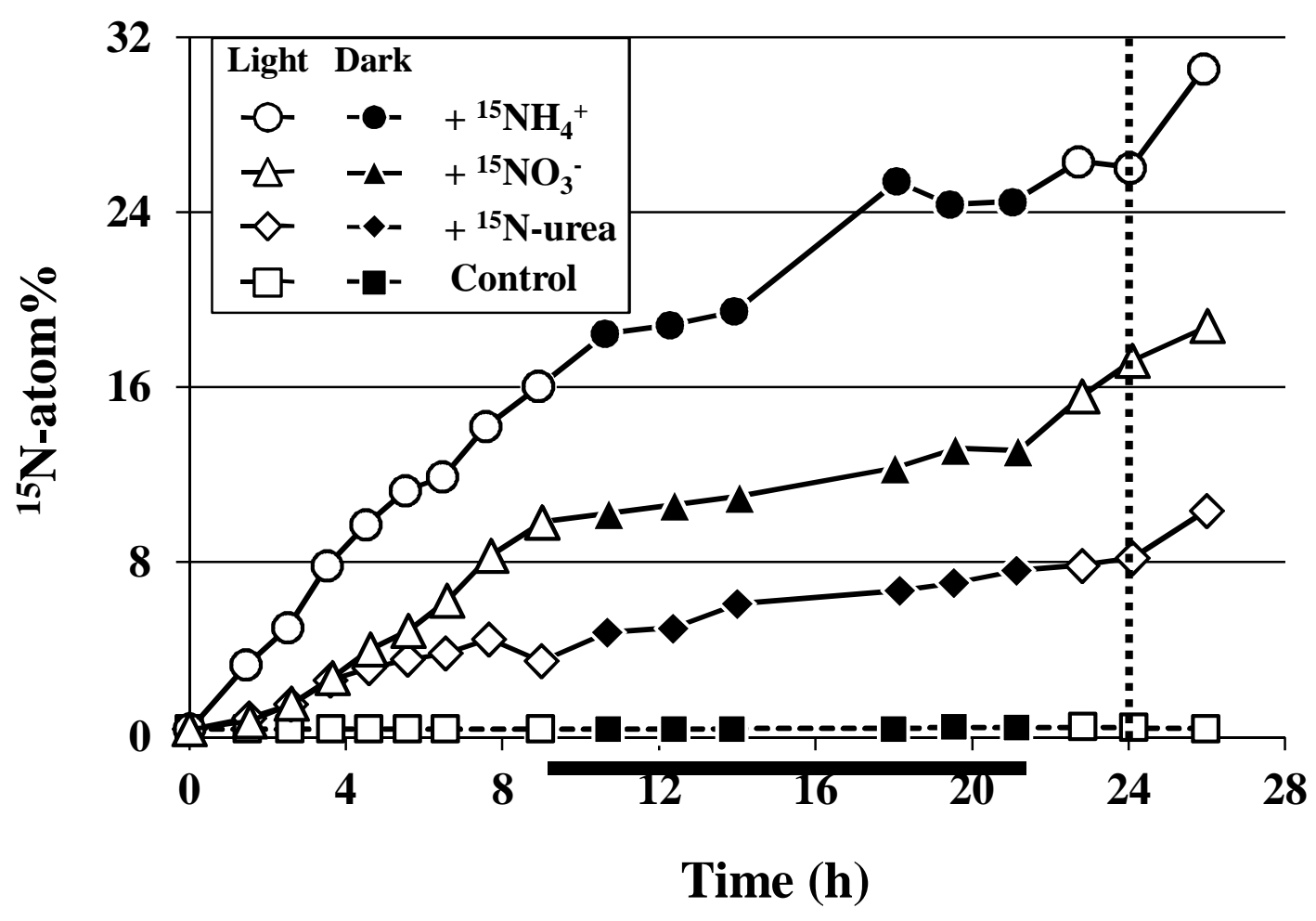


Fig. 3.Variations in ${ }^{13} \mathrm{C}$ isotopic ratios of Alexandrium catenella cells in $\mathrm{N}$-sufficient conditions, with ${ }^{15} \mathrm{NH}_{4}{ }^{+},{ }^{15} \mathrm{NO}_{3}{ }^{-}$or ${ }^{15} \mathrm{~N}$-urea additions, and without $\mathrm{N}$-addition. The dark period is indicated by the horizontal solid line and the end of the complete light:dark cycle $(24 \mathrm{~h})$ by the vertical dotted line.

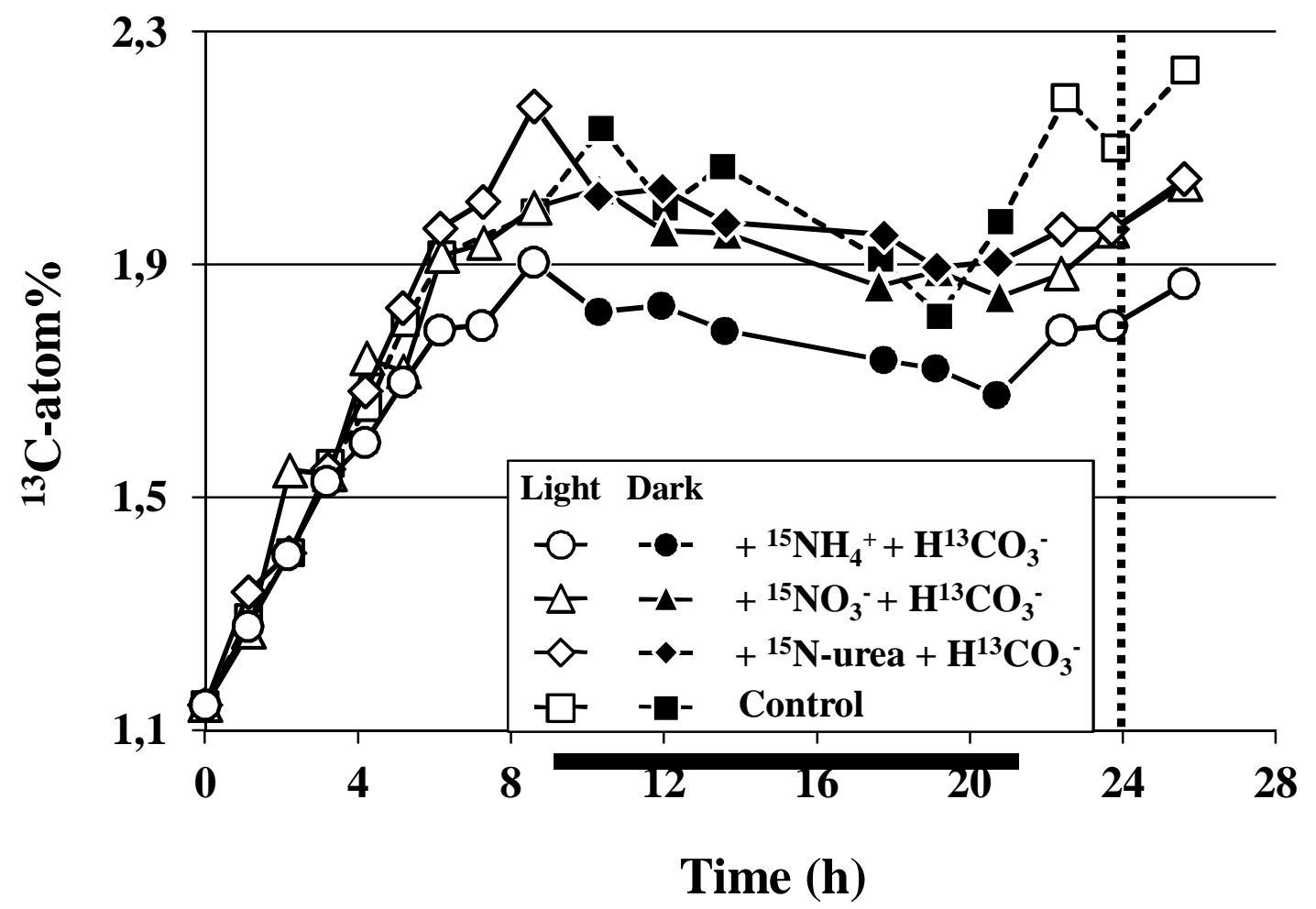


Fig. 4. Variations in $\mathrm{C}: \mathrm{N}$ composition ratios of Alexandrium catenellacells in $\mathrm{N}$ sufficient conditions, with ${ }^{15} \mathrm{NH}_{4}{ }^{+},{ }^{15} \mathrm{NO}_{3}{ }^{-}$or ${ }^{15} \mathrm{~N}$-urea additions, and without $\mathrm{N}$ addition. The dark period is indicated by the horizontal solid line and the end of the complete light:dark cycle $(24 \mathrm{~h})$ by the vertical dotted line.

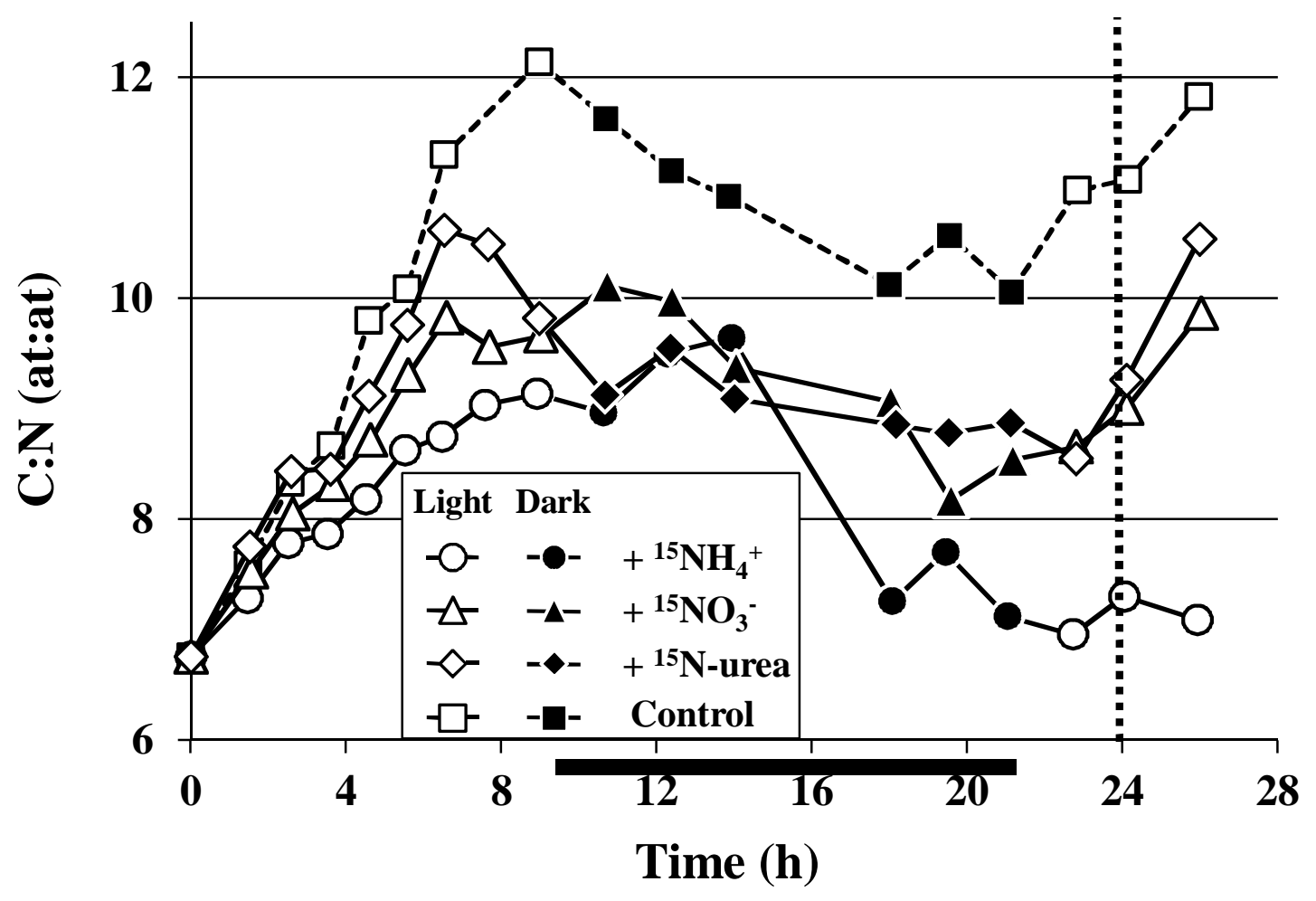


Fig. 5. Variations in ${ }^{15} \mathrm{~N}$ isotopic ratios of Alexandrium catenella cells after an initial pulse $\left(15 \mu\right.$ gat $\left.\mathrm{L}^{-1}\right)$ of ${ }^{15} \mathrm{NH}_{4}{ }^{+},{ }^{15} \mathrm{~N}-{ }^{13} \mathrm{C}$-urea and without ${ }^{15} \mathrm{~N}$-addition. The ${ }^{15} \mathrm{~N}-{ }^{13} \mathrm{C}$-urea data include the results obtained from both series, with and without supplementary addition of $\mathrm{H}^{13} \mathrm{CO}_{3}$. The vertical lines indicate standard deviations and the horizontal solid line the dark period.

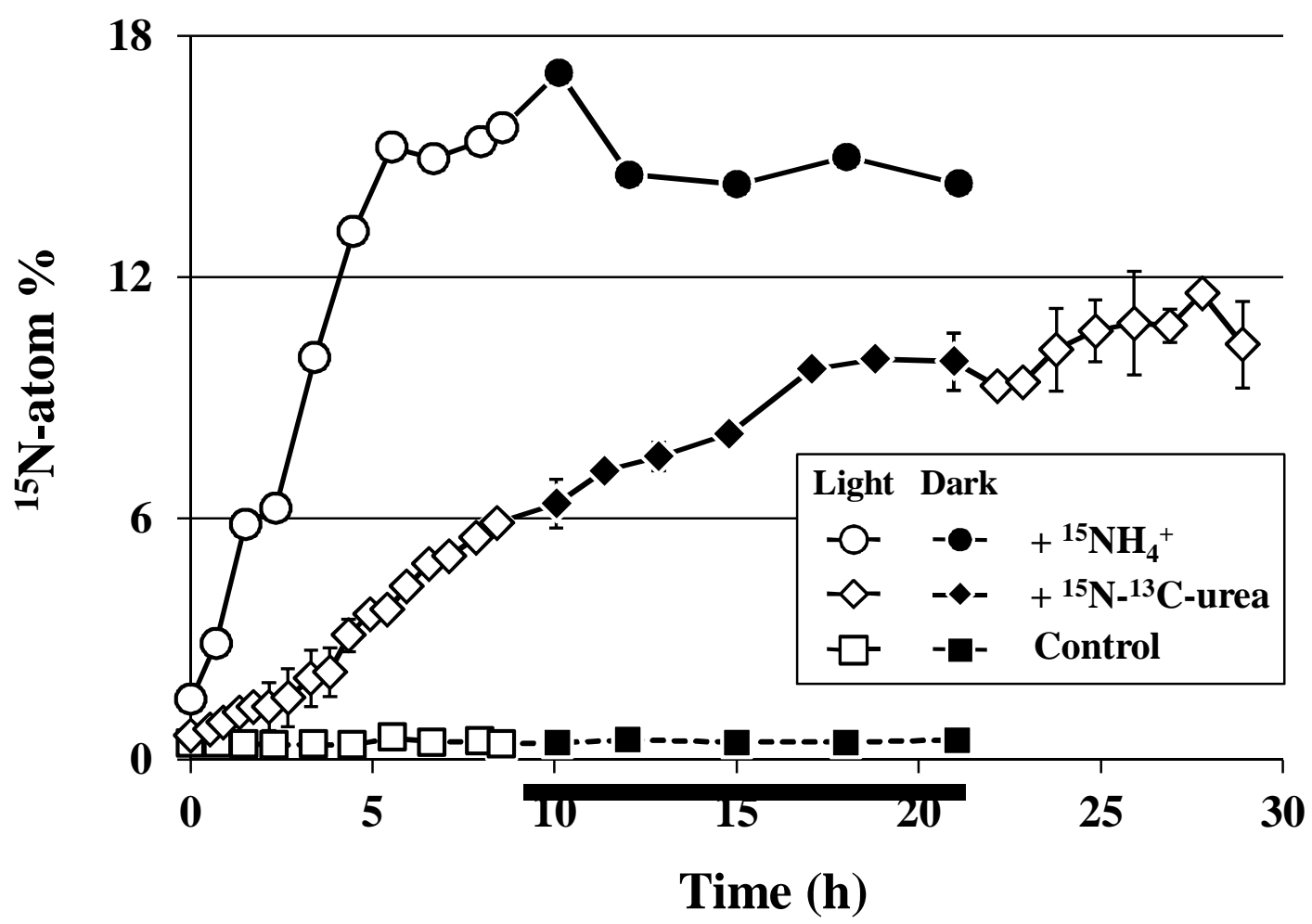


Fig. 6. Variations in ${ }^{13} \mathrm{C}$ isotopic ratio of Alexandrium catenella cells with or without initial pulses of ${ }^{15} \mathrm{~N}$ and ${ }^{13} \mathrm{C}$, in the form of ${ }^{15} \mathrm{NH}_{4}{ }^{+},{ }^{15} \mathrm{~N}-{ }^{13} \mathrm{C}$-ureaand $\mathrm{H}^{13} \mathrm{CO}_{3}{ }^{-}{ }^{15} \mathrm{~N}$ additions correspond to $15 \mu$ gat $\mathrm{N} \mathrm{L}^{-1}$ and $\mathrm{H}^{13} \mathrm{CO}_{3}{ }^{-}$additions to $78 \mu \mathrm{M}-\mathrm{C}$. The solid line indicates the dark period.

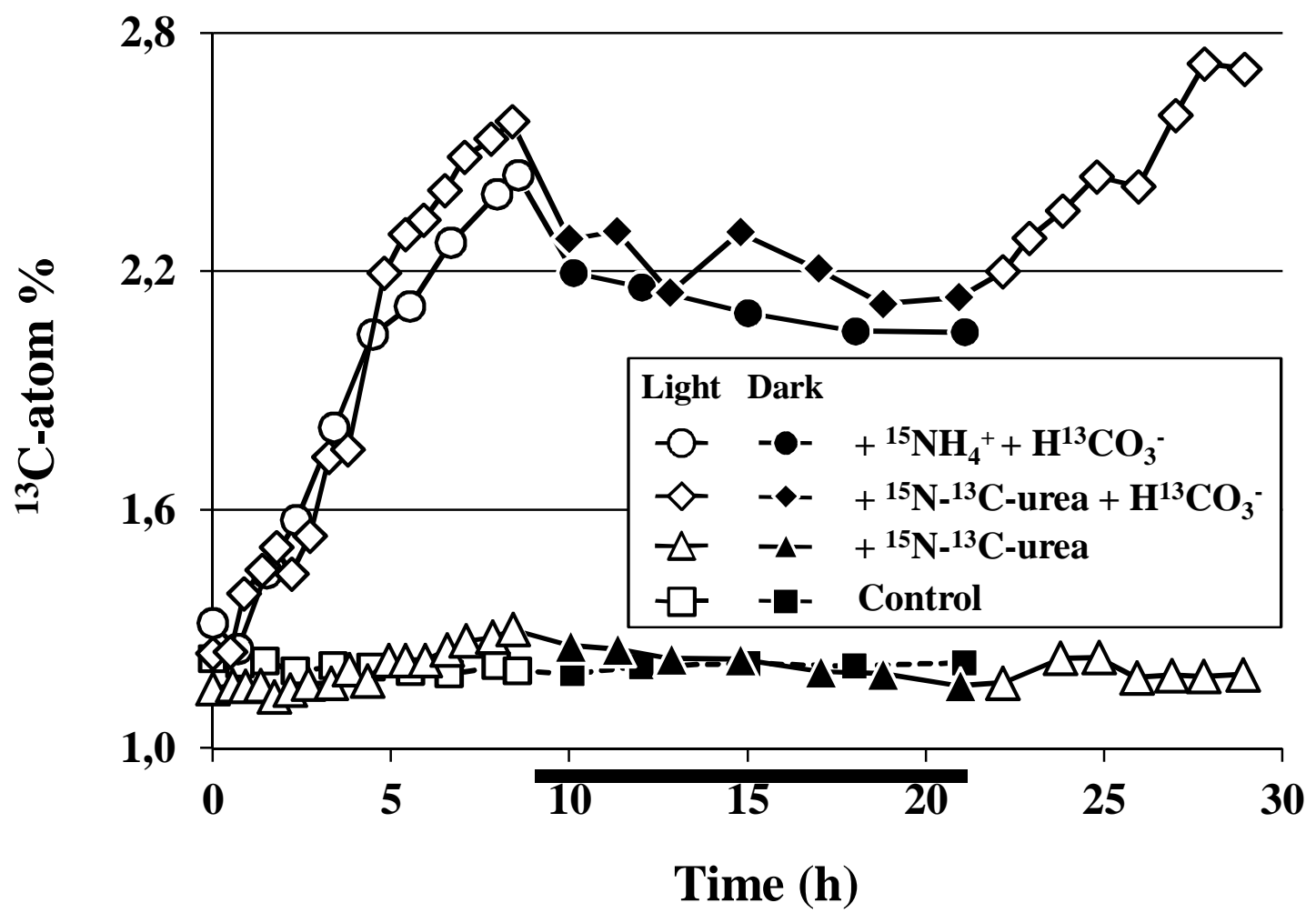

